\title{
Editorial: Teaching Matters
}

\author{
New Zealand Journal of Teachers' Work, Volume 14, Issue 2, 69-72, 2017
}

\section{NESTA DEVINE \& LEON BENADE Co-Editors}

The tone of this edition of New Zealand Journal of Teachers' Work is set by an eminent guest author, Gert Biesta, Professor of Education and Director of Research in the Department of Education of Brunel University in London. Biesta makes a claim in his latest book, The Rediscovery of Teaching (Biesta, 2017) that teaching and teachers actually matter. This claim may ordinarily not seem to be especially contentious or even significant, but given what he calls, the 'turn to learning', asserting the right of teachers to teach is becoming a matter of some critical relevance.

Under the provocative headline, 'Poor teacher training blamed for NZ education decline' The New Zealand Herald recently published a rather poor article based on an Education Review Office Report (Collins, 2017). This headline is a 'soundbite' that skews the context and the content of the ERO Report. It fails to recognise or acknowledge the complexities the ERO researchers report as contributing to the lack of confidence some graduates say they have. The ERO Report used a phenomenological approach, asking newly graduated teachers and school leaders, if they feltthought that new teachers were confident and prepared with regard to certain aspects of the job. The Herald might be forgiven for some confusion as the Review Office states elsewhere in the same Report that it wanted to learn about the experiences of newly graduated teachers as they entered the workforce, which is an entirely different research question.

The questions ERO asked the new graduate participants really put them on the spot: for instance, in the ECE area, they were asked (among other questions):

How confident and prepared do newly graduated teachers... feel/think they were in relation to using the EC curriculum, Te Whāriki, to:

...Design implement and evaluate a curriculum that is responsive to the language, culture and identity of all of the children they are responsible for in their service, particularly those children at risk of poor educational outcomes. (ERO, 2017, p. 10) 
Well-experienced teachers may admit to not feeling confident or extremely confident about these elements. Even well-intentioned, thoroughly professional teachers may misrecognise a student's needs, or the student's needs may be too complex for the teacher's skill set, and certainly no teacher can guarantee to be responsive to all the language needs that might occur in any group of students. We wish to add, the 'profiling' inherent in the phrase 'particularly those children at risk of poor educational outcomes' is risky in itself, since it invites typecasting and deficit thinking rather than respect, pedagogic analysis and support.

Indeed, in our mutual and respective experience, the ability of teachers to respond positively to needs of this kind is in inverse proportion to their confidence that they can do so: those who feel they know it all are the least likely to take the effort to find out, or listen, to students and their families as they attempt to explain. What initial teacher educators should be aiming to instil in their pre-service students is not a feeling of confidence and preparation but feelings of awe, responsibility, and joy in the exploration of the children's needs, new with every group, indeed new with the accumulation of experiences within the group. Modesty is a highly valuable and underrated virtue among teachers.

We could go on about the inadequacy both of the ERO report and the reporting of it, but most importantly we need to be aware that there has to be some significant political will to convert a phenomenological survey into evidence that poor teacher education is to blame for the decline in New Zealand's performance in international tests of educational achievement. This decline could not possibly be attributed to National Standards? Or to the consistent underfunding of New Zealand schools? Or to the equally consistent undermining of the standing of teachers? Gert Biesta's remarks in this issue about his book bring us squarely back to the importance of the teacher, and the dangers of fashionable pedagogic moves to sideline or dismiss what the teacher can bring to the student and their education.

The articles in this issue elaborate on the importance of what it is to be a teacher, and the process of teaching, each in various ways. Jane Gilbert has provided a significant and thought-provoking critique of the notion of 'makerspaces', suggesting three lenses through which the 'maker' movement can be understood. The one is through a notion that this movement coheres with calls for $21^{\text {st }}$ century learning, and another through what she terms 'digital literacy', which captures the ideas around BYOD and innovative learning environments, for example. Gilbert dismisses both as 'mis-educative', but sees potential in the maker movement should it involve working with ideas in new ways. Although, by her argument, if the democratising potential of the maker culture and the values it embodies are to be achieved, schooling as we know it today is under direct threat, yet, her argument implies the hovering presence of teachers, even if in radically reconstituted schooling scenarios.

The question of inclusion and exclusion is not settled only by policy-in fact, policy is no guarantee that otherwise marginalised groups will be included in the various dimensions of daily school life. As Hemi and Mortlock's research has indicated, in order for LGBT members of a school community to be successfully included requires teachers to actively and deliberately target bullying and exclusionary practices, while also making deliberate attempts to develop schools as safe places. 
Also on the theme of inclusion/exclusion, Kearney, Mentis and HollyBoen have shown that the lack of policy can in fact aid and encourage teacher agency and flexibility, this time in the role of Special Education Needs Coordinators (SENCOs). Remarkably, despite their widespread presence in schools around New Zealand, the Ministry of Education does not formally acknowledge or even fund their roles. This lack of formalisation, however, contend the authors, enables those in SENCO roles to carve their own niche in the schools where they operate.

The final article in this issue, by Neill, Corder, Wikitera and Cox, is an opportunity for a tertiary teaching team to reflect on the problematics of collaborative teaching on an interdisciplinary university paper. The authors demonstrate how such an arrangement is challenging at many levels, yet these challenges can be overcome by deliberate acts on the part of the teachers involved.

These various examples demonstrate what many in the teaching profession know-what is required is in any educative relationship is student (or 'learner', if you must), curriculum, teacher, and the intersection of all three dimensions. As Biesta has suggested, the 'turn to learning' may sound progressive, and the 'recovery' of teachers and teaching retrogressive, but distressingly, each call provides the opportunity to mount attacks on teachers (and, by extension, teacher educators). Apart from replacing us all with robots and Artificial Intelligence, we will do well to keep reminding ourselves that, whatever form it takes, education involves a human exchange of ideas, knowledge and skills, and to this extent, continues to be an ethical matter, one that is the poorer without the presence of the teacher. 


\section{REFERENCES}

Biesta, G.J.J. (2017). The rediscovery of teaching. New York, NY/London, United Kingdom: Routledge.

Collins, S. (2017, December 8). Poor teacher training blamed for NZ education decline. New Zealand Herald. Retrieved from http://www.nzherald.co.nz/nz/news/article.cfm?c id=1\&objectid=1195532 $\underline{4}$

Education Review Office. [ERO]. (2017). Newly graduated teachers: Preparation and confidence to teach. Retrieved from http://www.ero.govt.nz/publications/newly-graduated-teacherspreparation-and-confidence-to-teach 